\title{
Recurrent Miscarriage: Diagnostic and Therapeutic \\ Procedures. Guideline of the DGGG, OEGGG and SGGG \\ (S2k-Level, AWMF Registry Number 015/050)
}

\section{Diagnostik und Therapie von Frauen mit wiederholten Spontanaborten. Leitlinie der DGGG, OEGGG und SGGG (S2k-Niveau, AWMF-Registernummer 015/050)}

\section{(우(1) (요 $\ominus$}

Authors

Bettina Toth ${ }^{1}$, Wolfgang Würfel ${ }^{2}$, Michael Bohlmann ${ }^{3}$, Johannes Zschocke ${ }^{4}$, Sabine Rudnik-Schöneborn ${ }^{4}$, Frank Nawroth ${ }^{5}$, Ekkehard Schleußner ${ }^{6}$, Nina Rogenhofer ${ }^{7}$, Tewes Wischmann ${ }^{8}$, Michael von Wolff ${ }^{9}$, Katharina Hancke ${ }^{10}$, Sören von Otte ${ }^{11}$, Ruben Kuon ${ }^{12}$, Katharina Feil ${ }^{1}$, Clemens Tempfer ${ }^{13}$

Affiliations

1 Klinik für Gynäkologische Endokrinologie und Reproduktionsmedizin, Universität Innsbruck, Innsbruck, Austria

2 Kinderwunsch Centrum München, München, Germany

3 Universitätsfrauenklinik Mannheim, Mannheim, Germany

4 Zentrum für Medizinische Genetik, Universität Innsbruck, Innsbruck, Austria

5 Amedes, Hamburg, Germany

6 Klinik für Geburtsmedizin, Uniklinikum Jena, Jena, Germany

7 Klinikum der Universität München - Frauenklinik Maistraße, München, Germany

8 Institut für Medizinische Psychologie, Universitätsklinikum Heidelberg, Heidelberg, Germany

9 Universitätsklinik für Frauenheilkunde, Inselspital Bern, Bern, Switzerland

10 Klinik für Frauenheilkunde, Universitätsklinikum Ulm, Ulm, Germany

11 Kinderwunschzentrum, Universitätsklinikum SchleswigHolstein, Kiel, Germany

12 Universitäts-Frauenklinik Heidelberg, Heidelberg, Germany

13 Universitätsfrauenklinik, Ruhr-Universität Bochum, Bochum, Germany

Key words

recurrent miscarriage, incidence, diagnosis, therapy,

recommendations

Schlüsselwörter

wiederholter Spontanabort, Inzidenz, Diagnose, Therapie,

Empfehlungen

received 3.2.2018

revised 5.3.2018

accepted 6.3.2018
Bibliography

DOI https://doi.org/10.1055/a-0586-4568

Geburtsh Frauenheilk 2018; 78: 364-381 @ Georg Thieme

Verlag KG Stuttgart · New York | ISSN 0016-5751

Correspondence

Prof. Bettina Toth

Klinik für Gynäkologische Endokrinologie und Reproduktionsmedizin, Universität Innsbruck

Anichstraße 35, 6020 Innsbruck, Österreich

Bettina.toth@i-med.ac.at

丹eutsche Version unter:

https://doi.org/10.1055/a-0586-4568

\section{ABSTRACT}

Purpose Official guideline of the German Society of Gynecology and Obstetrics (DGGG), the Austrian Society of Gynecology and Obstetrics (ÖGGG) and the Swiss Society of Gynecology and Obstetrics (SGGG). The aim of this guideline was to standardize the diagnosis and treatment of couples with recurrent miscarriage (RM). Recommendations were based on the current literature and the views of the involved committee members.

Methods Based on the current literature, the committee members developed the statements and recommendations of this guideline in a formalized process which included DEL$\mathrm{PHI}$ rounds and a formal consensus meeting.

Recommendations Recommendations for the diagnosis and treatment of patients with RM were compiled based on the international literature. Specific established risk factors such as chromosomal, anatomical, endocrine, hemostatic, psychological, infectious and immunological disorders were taken into consideration. 


\section{ZUSAMMENFASSUNG}

Ziel Offizielle Leitlinie der Deutschen Gesellschaft für Gynäkologie und Geburtshilfe (DGGG), der Österreichischen Gesellschaft für Gynäkologie und Geburtshilfe (ÖGGG) und der Schweizerischen Gesellschaft für Gynäkologie und Geburtshilfe (SGGG). Ziel der Leitlinie ist es, die Diagnostik und Therapie des wiederholten Spontanaborts (WSA) anhand der aktuellen Literatur sowie der Erfahrung der Mitglieder der Leitlinienkommission evidenzbasiert zu standardisieren.

Methoden Anhand der internationalen Literatur entwickelten die Mitglieder der beteiligten Fachgesellschaften in einem formellen Prozess einen Konsensus. Empfehlungen und Statements der Leitlinie wurden in einem formalen Prozess (DELPHI-Prozess, Konsenstreffen mit moderiertem Abstimmungsprozess) erarbeitet und konsentiert.

Empfehlungen Es wurden Empfehlungen zur Diagnostik und Therapie von Paaren mit WSA anhand der internationalen Literatur erarbeitet. Insbesondere wurde auf die bekannten Risikofaktoren wie chromosomale, anatomische, endokrinologische, gerinnungsphysiologische, psychologische, infektiologische und immunologische Störungen eingegangen.

\section{Guideline Information}

\section{Guidelines program of the DGGG, OEGGG and SGGG}

Information on the guidelines program is available at the end of the guideline.

\section{Citation format}

Recurrent miscarriage: diagnostic and therapeutic procedures. Guideline of the DGGG, OEGGG and SGGG (S2k-Level, AWMF Registry Number 015/050). Geburtsh Frauenheilk 2018; 78 : 364-381

\section{Guideline documents}

The complete long version, a short version, a PDF slideshow for PowerPoint presentations and a summary of the conflicts of interest of all the authors are available in German on the AWMF homepage under: http://www.awmf.org/leitlinien/detail/I/015-050.html

\section{Guideline authors}

See $\vee$ Table 1.

- Table 1 The following professional and scientific societies/working groups/organisations/associations have stated their interest in contributing to the compilation of the guideline text and participating in the consensus conference and nominated representatives to attend the consensus conference.

\begin{tabular}{|c|c|}
\hline $\begin{array}{l}\text { Author } / \\
\text { Mandate holder }\end{array}$ & Working group/professional societies/organisations/associations \\
\hline \multicolumn{2}{|c|}{ Lead author and coordinating author: } \\
\hline Prof. Dr. Bettina Toth & $\begin{array}{l}\text { Austrian Society of Gynecology and Obstetrics (Österreichische Gesellschaft für Gynäkologie und Geburtshilfe [OEGGG]) } \\
\text { German Society of Gynecology and Obstetrics (Deutsche Gesellschaft für Gynäkologie und Geburtshilfe e. V. [DGGG]) } \\
\text { German Society for Gynecologic Endocrinology and Reproductive Medicine (Gesellschaft für Gynäkologische Endokri- } \\
\text { nologie und Fortpflanzungsmedizin [DGGEF]) }\end{array}$ \\
\hline Prof. Dr. Clemens Tempfer & German Society of Gynecology and Obstetrics (DGGG) \\
\hline \multicolumn{2}{|l|}{ Other lead authors: } \\
\hline Prof. Dr. Wolfgang Würfel & $\begin{array}{l}\text { German Society of Gynecology and Obstetrics (DGGG) } \\
\text { German Society for Gynecologic Endocrinology and Reproductive Medicine (DGGEF) }\end{array}$ \\
\hline Prof. Dr. M. Bohlmann & $\begin{array}{l}\text { German Society of Gynecology and Obstetrics (DGGG) } \\
\text { Working Group Immunology in the DGGG (Arbeitsgemeinschaft Immunologie in der DGGG [AGIM]) }\end{array}$ \\
\hline Prof. Dr. J. Zschocke & German Society of Human Genetics (Deutsche Gesellschaft für Humangenetik e. V. [GfH]) \\
\hline $\begin{array}{l}\text { Prof. Dr. } \\
\text { S. Rudnik-Schöneborn }\end{array}$ & German Society of Human Genetics (GfH) \\
\hline Prof. Dr. E. Schleußner & German Society of Ultrasound in Medicine (Deutsche Gesellschaft für Ultraschall in der Medizin e. V. [DEGUM]) \\
\hline PD Dr. N. Rogenhofer & Working Group Immunology in the DGGG (AGIM) \\
\hline Prof. Dr. T. Wischmann & German Society for Fertility Counselling (Deutsche Gesellschaft für Kinderwunschberatung [BKiD]) \\
\hline Prof. Dr. M. von Wolff & Swiss Society of Gynecology and Obstetrics (Schweizerische Gesellschaft für Gynäkologie und Geburtshilfe [SGGG]) \\
\hline Prof. Dr. K. Hancke & German Society of Reproductive Medicine (Deutsche Gesellschaft für Reproduktionsmedizin [DGRM]) \\
\hline PD Dr. S. von Otte & Professional Association of Gynecologists (Berufsverband der Frauenärzte [BVF]) \\
\hline
\end{tabular}




$\begin{array}{ll}\text { Abbreviations } \\ \text { Ab } & \text { antibodies } \\ \text { ANA } & \text { antinuclear antibodies } \\ \text { aPL } & \text { antiphospholipid } \\ \text { APS } & \text { antiphospholipid syndrome } \\ \text { ASA } & \text { acetylsalicylic acid } \\ \text { ASRM } & \text { American Society for Reproductive Medicine } \\ \text { FVL } & \text { factor V Leiden } \\ \text { G-CSF } & \text { granulocyte colony-stimulating factor } \\ \text { GM-CSF } & \text { granulocyte-macrophage colony-stimulating factor } \\ \text { GW } & \text { week of gestation } \\ \text { HLA } & \text { human leukocyte antigen } \\ \text { IVIG } & \text { intravenous immunoglobulin } \\ \text { LBR } & \text { live birth rate } \\ \text { LIT } & \text { lymphocyte immunization therapy } \\ \text { LMWH } & \text { low-molecular-weight heparin } \\ \text { NK } & \text { natural killer } \\ \text { PCO } & \text { polycystic ovaries } \\ \text { PGD } & \text { preimplantation genetic diagnosis } \\ \text { RCOG } & \text { Royal College of Obstetricians and Gynaecologists } \\ \text { RM } & \text { recurrent miscarriage } \\ \text { PT } & \text { prothrombin } \\ \text { SGA } & \text { small for gestational age } \\ \text { S/P } & \text { status post } \\ \text { TPO } & \text { thyroid peroxidase } \\ \text { TSH } & \text { thyroid-stimulating hormone } \\ \text { VTE } & \text { venous thromboembolism } \\ & \\ \text { II } & \text { Guideline Application } \\ & \end{array}$

\section{Purpose and objectives}

The aim of this guideline is to standardize the diagnosis and treatment of couples with recurrent miscarriage (RM) based on the most current national and international literature.

\section{Targeted areas of patient care}

Outpatient and/or inpatient care.

\section{Target user groups/target audience}

The recommendations of the guideline are addressed to gynecologists and their colleagues working in medical fields such as human genetics, psychotherapy, laboratory medicine, hemostasis, internal and general medicine and other professional staff involved in the care of patients with RM. Targeted patient group: couples with RM

\section{Adoption of the guideline and period of validity}

The validity of this guideline was confirmed by the respective boards/representatives of the participating professional medical societies, working groups, organizations and associations, by the board of the DGGG, SGGG and OEGGG and the DGGG/OEGGG/ SGGG Guideline Commission in January 2018 and thereby approved in its entirety. This guideline is valid from February 1, 2018 through to January 31, 2021. The above-mentioned period of validity is only an estimate. The guideline can be updated earlier if urgently required. Should the guideline continue to reflect the current level of scientific knowledge, then the guideline's period of validity can be extended.

\section{Methodology}

\section{Basic principles}

Because of the complex biological processes which occur in the context of RM and the heterogeneity of the studies published on this topic, there is widespread uncertainty about the optimal individual diagnosis and therapy of women with RM. An updated S2klevel guideline was therefore considered advisable to improve the quality of care. The guideline aims to provide information and advice for women with RM about appropriate diagnostic procedures and evidence-based treatment strategies. In addition, the recommendations of the guideline should serve as the basis for interdisciplinary decision-making.

This guideline is based on the S1 guideline "Recurrent Miscarriage: Diagnostic and Therapeutic Procedures" (AWMF 015/050), published in 2013, and the results of a recent literature search (as per September 2017). The relevant literature was assigned to the various chapters with the help of degree candidate Eva Preisl and Dr. Katharina Feil, both from the University Hospital for Gynecological Endocrinology and Reproductive Medicine, Innsbruck, Austria. A coherent draft version was compiled from the individual chapters, which was edited in a joint advance consensus. Statements and recommendations which took the form of unambiguous instructions were then extracted from the draft text. The revised text was subsequently circulated among all the member of the guideline commission. The members proposed changes to the text and voted on the final manuscript.

This guideline is classified as: S2k

\section{Grading of recommendations}

As no systematic search, selection, evaluation and synthesis of the evidence base was carried out, the guideline does not discuss levels of evidence. The recommendations are graded as follows ( Table 2):

- Table 2 Grading of recommendations according to the respective syntax.

\begin{tabular}{|l|l|}
\hline Description & Syntax \\
\hline Strong recommendation, strongly binding & must \\
\hline Recommendation, moderately binding & should \\
\hline Open recommendation, not binding & may \\
\hline
\end{tabular}

\section{Statements}

Expert statements included in this guideline which are not recommendations for action but are simple statements of fact are referred to as "Statements". It is not possible to provide a level of evidence for these statements. 


\section{Achieving consensus and level of consensus}

An interdisciplinary group voted on the statements and recommendations at three consensus conferences. The statements and recommendations of the guideline were discussed at consensus conferences held on 20th April 2017, 6th June 2017 and 19th September 2017 in Munich. Following a moderated formal consensus process, the participants of the conferences jointly consented to the statements and recommendations. The consent protocol is available on request.

During the compilation of this guideline, special consideration was given to existing recommendations (the guideline was first compiled in 2006 and revised in 2008 and 2013), the recommendations of the European Society of Human Reproduction and Embryology (ESHRE 2017), the Royal College of Obstetricians and Gynecologists [1], the American College of Obstetricians and Gynecologists (ACOG 2002) [2] and the American Society for Reproductive Medicine (ASRM 2012) [3].

During structured consensus-based decision-making (S2k/S3 level), authorized participants present at a session vote on draft Statements and Recommendations. Discussions during sessions may lead to significant changes in the wording of Statements and Recommendations, etc. The extent of agreement, which depends on the number of participants, is determined at the end of the session ( $\vee$ Table 3 ).

- Table 3 Classification of extent of agreement in consensus decision-making.

\begin{tabular}{|l|l|l|}
\hline Symbol & Level of consensus & $\begin{array}{l}\text { Extent of agreement } \\
\text { in percent }\end{array}$ \\
\hline+++ & Strong consensus & $>95 \%$ of participants agree \\
\hline++ & Consensus & $>75-95 \%$ of participants agree \\
\hline+ & Majority agreement & $>50-75 \%$ of participants agree \\
\hline- & No consensus & $<50 \%$ of participants agree \\
\hline
\end{tabular}

\section{Expert consensus}

As the name implies, this refers to consensus decisions taken with regard to specific Recommendations/Statements without a previous systematic search of the literature $(S 2 k)$ or when evidence is lacking (S2e/S3). The term "Expert Consensus" (EC) used here is synonymous with terms such as "Good Clinical Practice" (GCP) or "Clinical Consensus Point" (CPP) used in other guidelines. The level of recommendation is graded as previously described in the Chapter "Grading of recommendations" but only semantically ("must/must not" or "should/should not" or "may/may not") and without using the symbols shown there.

\section{Guideline}

\section{Introduction}

Counselling and treating couples with RM is a diagnostic and therapeutic challenge as several possible causes for RM are known, but no risk factor for RM is identified in the majority of affected patients.

\section{Incidence and Definition}

Approximately $1-3 \%$ of all couples of reproductive age experience recurrent miscarriage [4]. A miscarriage is defined as the loss of a fetus at any time between conception and the 24th week of gestation (GW) or the loss of a fetus weighing < $500 \mathrm{~g}$ [5]. The World Health Organization (WHO) definition of recurrent spontaneous miscarriage is: "three and more consecutive miscarriages before the 20th GW" [5]. The American Society for Reproductive Medicine (ASRM) already defines the occurrence of two consecutive miscarriages as RM $[3,6]$. This definition increases the incidence of RM to $5 \%$ of all couples of reproductive age [7]. This guideline takes the WHO definition ( $\geq 3$ consecutive recurrent miscarriages) as the basis for its recommendations on diagnostic and therapeutic procedures.

If a woman has not previously given birth to a live infant, the loss of the fetus is referred to as primary RM; if the woman has had a previous live birth, the pregnancy loss is referred to as secondary RM [8]. Another classification, which refers to the course of the miscarriages, classifies miscarriages into repeated loss of embryonic pregnancy (sporadic loss) or loss of fetal pregnancy (detectable heart beat on sonography or histologically verifiable embryo) [3].

The risk of recurrent miscarriage varies significantly, depending on a number of different factors. In addition to maternal age, the number of previous miscarriages also affects the risk of recurrence. - Table 4 presents the data from a retrospective registry study [9].

- Table 4 Probability of recurrent miscarriage depending on maternal age and the number of previous miscarriages, based on the study of NyboAndersen et al. [9].

\begin{tabular}{|l|l|l|l|}
\hline Previous miscarriages & Risk of recurrence & & $35-39$ years \\
\hline & $\mathbf{2 5 - 2 9}$ years & $\mathbf{3 0 - 3 4}$ years & $\sim 21-23 \%$ \\
\hline 1 miscarriage & $\sim 15 \%$ & $\sim 16-18 \%$ & $\sim 40 \%$ \\
\hline 2 miscarriages & $\sim 22-24 \%$ & $\sim 23-26 \%$ & $\sim 25-30 \%$ \\
\hline$\geq 3$ miscarriages & $\sim 40-42 \%$ & $\sim 38-40 \%$ & $\sim 40-45 \%$ \\
\hline
\end{tabular}




\section{Diagnosis and Treatment of Relevant Risk Factors}

3.1 Lifestyle and behavior

\subsubsection{Stress}

Some studies have indicated that higher stress levels during pregnancy might be associated with an increased risk of pregnancy loss. A case-control study of 45 patients with RM concluded that stress levels were higher compared to 40 control patients [10]. A study of 301 patients with RM (defined as $\geq 3$ miscarriages) compared to women wanting to children reported similar findings [11]. Because of the small number of cases, it is not possible, based on the currently available data, to conclude that stress increases the risk of miscarriage.

\subsubsection{Coffee consumption}

A few observational studies have reported a dose-dependent relationship between coffee intake and late loss of pregnancy [12]. A larger case-control study was also able to show that coffee consumption had an impact on early miscarriage [13]. Another retrospective case-control study demonstrated a significantly increased risk of RM following coffee consumption in the periconceptional period and in early pregnancy. It was not possible to show a linear association between the amount of coffee consumed and the risk of RM [14].

\subsubsection{Nicotine and alcohol consumption}

There is a strong association between nicotine consumption and poor obstetric and neonatal outcomes such as ectopic pregnancy, stillbirth, placenta previa, premature birth, low birthweight and congenital malformation. Cessation of smoking should therefore be recommended to all pregnant women [15]. The impact of smoking and of cessation of smoking on the risk of RM is not clear. A retrospective study compared 326 patients with RM with 400 control patients who had had at least one live birth. The study showed that even passive smoking significantly increased the risk of RM [16]. Another study came to the conclusion that maternal nicotine, alcohol or coffee consumption was not associated with a higher probability of RM [17].

A prospective study, which evaluated the impact of paternal smoking on the risk of miscarriage, investigated 526 couples and was able to show that women who were heavy smokers (> 20 cigarettes per day) had a higher risk of early miscarriage. Heavy smoking (more than 20 cigarettes per day) had a significantly greater impact than moderate smoking ( $<20$ cigarettes per day) [18]. There are currently no studies on the impact of smoking cessation on the chances of giving birth to a live infant for couples with RM.

\subsection{Genetic factors}

\subsubsection{Chromosomal anomalies}

Embryonic/fetal chromosomal abnormalities are the most common cause of spontaneous miscarriage $[19,20]$. The earlier the miscarriage occurs, the more likely that an embryonic/fetal chromosomal anomaly was present [21]. The risk of embryonic/fetal trisomy resulting from chromosomal aberrations increases with higher maternal age. The most common cause of miscarriage is trisomy 16 , followed by trisomy 22 . Triploidy was detected in ap- proximately $15 \%$ of cytogenetically abnormal fetuses. Monosomy $X$ is responsible for approximately $20 \%$ of miscarriages which occur in the first trimester of pregnancy. No association with maternal age has been found for monosomy $X$, polyploidy or structural chromosomal disorders [22]. A balanced chromosomal abnormality in one of the partners was confirmed in around $4-5 \%$ of couples who had 2 or more miscarriages [23]. In around $1 \%$ of pregnancies, an unbalanced set of chromosomes was detected during prenatal diagnostic procedures or after the birth [24,25].

Consensus-based Recommendation 3-2.E1

\begin{tabular}{l|l} 
Expert consensus $\quad$ Level of consensus ++
\end{tabular}

Cytogenetic analysis must be done if a woman experiences recurrent miscarriages. This can be done either by chromosome analysis of both partners prior to conception or using tissue samples from the miscarried fetus.

It is not possible to carry out standard chromosomal analysis in around $18 \%$ of miscarried fetuses, and array analysis cannot be done in around $5 \%$ of miscarried fetuses [26]. Overall, molecular cytogenetic analysis only detected additional chromosomal disorders in around $5 \%$ of cases, and the routine use of array analysis to identify the cause of miscarriage is therefore not useful at present [26].

Consensus-based Recommendation 3-2.E2

Expert consensus Level of consensus +++

Both partners must undergo cytogenetic testing if a structural chromosomal disorder is detected in the tissue of the miscarried fetus. The couple must be informed of the findings during genetic counselling carried out by a specialist for human genetics or a physician with the relevant qualifications in accordance with national legal regulations.

\section{Consensus-based Statement 3-2.51}

Expert consensus Level of consensus ++

If a balanced chromosomal aberration is detected in one of the parents, the risk of miscarriage or of giving birth to an infant with a chromosomal disorder increases, depending on the chromosomes involved. This will affect antenatal diagnostic procedures in any further pregnancies.

\subsubsection{Monogenetic disease}

$\mathrm{X}$-linked dominant disorders that are lethal in males have an increased risk of miscarriage. But autosomal dominant and recessive disorders with severe malformations can also result in increased intrauterine mortality. In these cases, examination of the fetus should include genetic and pathological testing, particularly if the disorder was not identified prenatally. 
Consensus-based Recommendation 3-2.E3

Expert consensus

Level of consensus ++

If there are indications that monogenetic disease may be the cause of miscarriage, genetic counselling must include genetic testing.

\subsubsection{Results of association studies}

Numerous studies suggest possible maternal, paternal or fetal genetic effects, but these appear to have very little impact on the risk of miscarriage [27].

\begin{tabular}{|c|c|}
\hline \multicolumn{2}{|c|}{ Consensus-based Recommendation 3-2.E4 } \\
\hline Expert consensus & Level of consensus +++ \\
\hline \multicolumn{2}{|c|}{$\begin{array}{l}\text { Molecular genetic analysis for gene variants detected in association studies } \\
\text { is not recommended for couples with RM. }\end{array}$} \\
\hline
\end{tabular}

\subsubsection{Therapeutic options}

It is not possible to treat the causes of chromosomal disorders. Previous studies have not shown that PGD after IVF results in an increased rate of live births in women with RM compared to spontaneous pregnancies, not even for couples who are genetically at risk because one partner has a balanced chromosomal aberration. Neither the ESHRE and RCOG guidelines nor the ASRM Statement recommend preimplantation genetic diagnosis for couples with RM.

\begin{tabular}{|l|}
\hline \multicolumn{1}{|c|}{ Consensus-based Recommendation 3-2.E5 } \\
\hline \multicolumn{1}{|c|}{ Expert consensus } \\
\hline $\begin{array}{l}\text { Preimplantation genetic diagnosis to prevent miscarriage is not recom- } \\
\text { mended for couples with RM who have no familial chromosomal disorder } \\
\text { and no monogenetic disease. }\end{array}$
\end{tabular}

\subsection{Anatomical factors}

\subsubsection{Diagnosis of anatomical factors}

\subsubsection{Congenital malformations}

Hysteroscopic examinations of patients who had 2, 3 and $\geq 4$ consecutive miscarriages found no difference in the prevalence of congenital (uterine malformations) or acquired (adhesions, polyps, submucosal fibroids) intrauterine pathologies [28]. The increased probability of miscarriage in women with subseptate uterus is well known, but the cause of this association is unknown [29]. It is not clear whether there is an association between RM and other uterine malformations such as arcuate uterus or bicornuate uterus. Ludwin et al. [30] reported significantly better diagnostic results when using sonohysterography (SHG) to diagnose congenital uterine malformations compared with hysterosalpingography (HSG) or hysteroscopy. But it is difficult to evaluate statements comparing diagnostic methods, because even when hysteroscopy videos were presented to experienced international observers, interobserver agreement was found to be poor [31].
When diagnosing uterine malformations, the decision whether to use hysteroscopy - possibly in combination with laparoscopy or 3D sonography - must be made on an individual basis [32]. $3 \mathrm{D}$ sonography is recommended for the diagnostic workup of uterine malformations in high-risk populations and MRI and endoscopic examinations are recommended for diagnostic problems or suspected complex malformations [33].

\subsubsection{Acquired malformations}

Although the study populations consisted only of women undergoing IVF, a meta-analysis of 19 observational studies showed a higher but not statistically significant rate of miscarriages in women with intramural fibroids and no submucosal involvement (relative risk [RR] 1.24; 95\% Cl: 0.99-1.57) [34]. In an evaluation of retrospective and prospective data of patients with RM, the incidence of submucosal fibroids was $2.6 \%$ (25/966) [35]. These study data suggest an association between submucosal fibroids and the occurrence of miscarriage, but the quality of the data is poor. A Cochrane analysis which only included a few studies showed no significant reduction in the risk of miscarriage after uterine fibroids had been resected (intramural: OR 0.89, $95 \% \mathrm{Cl}$ : 0.14-5.48; submucosal: OR 0.63, 95\% Cl: 0.09-4.40) [36].

It is not clear whether - as with submucosal fibroids - intracavitary polyps also increase the risk of miscarriage.

\begin{tabular}{l} 
Consensus-based Recommendation 3-3.E6 \\
\hline \multicolumn{1}{|c|}{ Expert consensus } \\
\hline Vaginal sonography and/or hysteroscopy is recommended in women with \\
RM to rule out uterine malformations, submucosal uterine fibroids and \\
polyps. Hysteroscopy is recommended to rule out intrauterine adhesions.
\end{tabular}

\subsubsection{Treatment for anatomical factors}

Hysteroscopic septum dissection is recommended for women with RM and septate uterus [37]. A meta-analysis carried out in 2017 showed that no randomized studies on the therapeutic effect of septum dissection have been carried out to date [38]. But retrospective uncontrolled studies suggest that the surgical intervention is beneficial. Postoperative healing takes about 2 months [39], and there are no reasons to avoid pregnancy thereafter. Surgical intervention is not indicated for other uterine malformations such as bicornuate uterus, uterus didelphys and arcuate uterus [40-42].

\section{Consensus-based Recommendation 3-3.E7} Expert consensus Level of consensus +++

Hysteroscopic septum resection is recommended to treat women with RM and septate uterus. 
Hysteroscopic adhesiolysis is the therapy of choice to treat intrauterine adhesions [43]. It is not clear whether or to what extent intrauterine adhesions affect the risk of miscarriage and whether adhesiolysis will reduce the risk of RM.

\begin{tabular}{l} 
Consensus-based Recommendation 3-3.E8 \\
\hline \multicolumn{1}{|c|}{ Expert consensus } \\
\hline $\begin{array}{l}\text { Hysteroscopic of consensus ++ } \\
\text { intrauterine adhesions. }\end{array}$ \\
\hline
\end{tabular}

There are no randomized studies on the therapeutic benefits of fibroid resection in women with RM.

\begin{tabular}{l}
\hline \multicolumn{1}{|c|}{ Consensus-based Recommendation 3-3.E9 } \\
\hline \multicolumn{1}{|c|}{ Expert consensus } \\
\hline Surgical resection should be performed in women with RM and submucosal \\
fibroids.
\end{tabular}

A meta-analysis showed that hysteroscopic resection of intrauterine polyps visible on ultrasound carried out before intrauterine insemination can increase clinical pregnancy rates [44]. The resection of persistent polyps can be considered if there is no other explanation for RM.

\begin{tabular}{l}
\hline \multicolumn{1}{|c|}{ Consensus-based Recommendation 3-3.E10 } \\
\hline \multicolumn{1}{|c|}{ Expert consensus } \\
\hline $\begin{array}{l}\text { Hysteroscopic resection should be consensus ++ } \\
\text { women with RM and persistent polyps. }\end{array}$ \\
\hline
\end{tabular}

\subsection{Microbiological factors}

\subsubsection{Diagnostic workup of microbiological factors}

Because the association between infections and RM is unclear, general screening for vaginal infections which goes beyond the routine screening carried out as part of prenatal care is not recommended. However, chronic endometritis, as evidenced by the finding of plasma cells in the endometrial biopsy, was detected in $7-67 \%$ of otherwise asymptomatic women with RM and in 30$66 \%$ of women with recurrent implantation failure [45-49]. Endometrial biopsy may be performed in women with RM to exclude chronic endometritis (supported by immunohistochemical staining for the plasma cell surface antigen CD138).

\section{Consensus-based Recommendation 3-4.E11}

\section{Expert consensus}

Level of consensus +++

Infectious screening using vaginal swab specimens is not recommended in asymptomatic women with RM.

\section{Consensus-based Recommendation 3-4.E12}

\section{Expert consensus}

Level of consensus ++

An endometrial biopsy may be performed in women with RM to rule out chronic endometritis (supported by immunohistochemical staining for the plasma cell surface antigen CD138).

\subsubsection{Treatment for microbiological factors}

Pregnant women suspected of having a vaginal infection should receive proper testing and treatment $[50,51]$. Antibiotic therapy with doxycycline (e.g. $200 \mathrm{mg} 1-0-0$ for 14 days) is indicated for chronic endometritis; in the event of persistent endometritis as evidenced by the persistence of plasma cells, treatment can consist of ciprofloxacin with/without metronidazole [45].

\begin{tabular}{|l|l|}
\hline \multicolumn{1}{|c|}{ Consensus-based Recommendation 3-4.E13 } \\
\hline \multicolumn{1}{|c|}{ Expert consensus } \\
\hline $\begin{array}{l}\text { Antibiotic therapy may be administered to women with RM and chronic } \\
\text { endometritis to prevent miscarriage. }\end{array}$
\end{tabular}

\subsection{Endocrine factors}

\subsubsection{Diagnostic workup of endocrine factors}

According to a retrospective analysis, manifest hyperthyroidism is associated with increased miscarriage rates [52]. This also applies to manifest hypothyroidism. It is still unclear, however, whether latent hypothyroidism (i.e. increases in TSH concentrations despite thyroid hormone concentrations within normal ranges) also increases the risk of miscarriage. A meta-analysis of two studies reported that the LBR was not lower for women with RM and TSH concentrations of $>2.5 \mathrm{mU} / \mathrm{L}$ [53]. Increased levels of thyroid hormone autoantibodies appear to be associated with higher rates of spontaneous miscarriage [54]. PCOS, hyperandrogenemia (which is often PCOS-related [55]), insulin resistance [56, 57] and diabetes [58] are all associated with a higher tendency to miscarry. PCOS per se is not a predictive factor for miscarriage or RM [59], whereas obesity per se appears to increase the rate of miscarriages.

\section{Consensus-based Recommendation 3-5.E14}

Expert consensus

Level of consensus ++

An endocrine workup determining TSH levels is recommended in women with RM. If TSH levels are found to be abnormal, fT3, fT4 and thyroid hormone autoantibody concentrations must also be determined.

Consensus-based Recommendation 3-5.E15

Expert consensus Level of consensus +++

The BMI of women with RM should be determined. Women with a BMI $\geq 30 \mathrm{~kg} / \mathrm{m}^{2}$ may be investigated further to determine whether they have a metabolic syndrome. 


\subsubsection{Treatment for endocrine factors}

It is important to diagnose and treat manifest hyperthyroidism or hypothyroidism. A meta-analysis of studies of IVF patients with increased levels of thyroid hormone autoantibodies (RM was no inclusion criterion) and pregnant women with higher levels of TPO antibodies showed that substitution of thyroid hormones decreased the rate of miscarriages [54]. No statement was made about the rate of live births. However, other studies such as the study by Negro et al. published in 2016 [60] were unable to demonstrate the effect. It is therefore possible that patients with RM and TPO autoantibodies benefit from the substitution of thyroid hormones in terms of a lower rate of miscarriages, but currently there is no data specifically on patients with RM.

\begin{tabular}{|l|l|}
\hline \multicolumn{2}{|c|}{ Consensus-based Recommendation 3-5.E16 } \\
\hline \multicolumn{1}{|c|}{ Expert consensus } & Level of consensus +++ \\
\hline $\begin{array}{l}\text { Manifest hypothyroidism or hyperthyroidism must be treated before con- } \\
\text { ception. }\end{array}$ \\
\hline
\end{tabular}

\begin{tabular}{|c|c|}
\hline \multicolumn{2}{|c|}{ Consensus-based Recommendation 3-5.E17 } \\
\hline Expert consensus & Level of consensus ++ \\
\hline \multicolumn{2}{|c|}{$\begin{array}{l}\text { Thyroid hormone substitution therapy can be administered to prevent } \\
\text { miscarriage in women with RM and latent hypothyroidism, i.e. patholog- } \\
\text { ically increased TSH concentrations despite fT3 and fT } 4 \text { concentrations } \\
\text { within normal ranges or the presence of TPO autoantibodies. }\end{array}$} \\
\hline
\end{tabular}

A meta-analysis found that the administration of metformin had no effect on the risk of sporadic miscarriage [61], and the guideline can therefore not make any recommendation regarding the administration of metformin.

There are many medical reasons why women with a high BMI should lose weight (cf. the S3 guideline on "Gestational Diabetes", AWMF guideline 057/008). A Danish cohort study [62] showed that the risk of miscarriage increases for women with a BMI $\geq 30 \mathrm{~kg} / \mathrm{m}^{2}$ (OR 1.23; $95 \% \mathrm{Cl}: 0.98-1.54$ ).

Consensus-based Recommendation 3-5.E18

Expert consensus Level of consensus +++

Women with RM and a high body mass index should be encouraged to lose weight.

\subsection{Psychological factors}

Evidence-based medicine has not been able to show that RM can be directly caused by psychological factors such as stress alone $[10,63,64]$.
Consensus-based Recommendation 3-6.E19

\section{Expert consensus}

Level of consensus +++

Women with a prior history of mental illness, women who are involuntarily childless, and women who lack or have only limited social resources or are struggling with feelings of guilt related to processing their experience of RM must be given information about psychosocial assistance and support (including self-help groups and internet forums).

\section{Consensus-based Recommendation 3-6.E20}

\section{Expert consensus}

Level of consensus +++

A psychotherapist must be called in if there is a suspicion that the patient is suffering from reactive depression following RM to determine whether the affected patient/couple require(s) further treatment.

\begin{tabular}{l}
\hline \multicolumn{1}{|c|}{ Consensus-based Statement 3-6.S2 } \\
\hline \multicolumn{1}{|c|}{ Expert consensus } \\
\hline $\begin{array}{l}\text { The efficacy of "tender loving care" as a therapeutic intervention to prevent } \\
\text { miscarriage in women with RM is not proven. However, tender loving care } \\
\text { can provide psychological support. }\end{array}$
\end{tabular}

\subsection{Immunological factors}

\subsubsection{Diagnosis of immunological factors \\ 3.7.1.1 Alloimmune factors}

Activation of the immune system (particularly of the Th1 response) results in unfavorable conditions for implantation and is associated with an increased probability of RM [51,65-69]. It has not yet been clearly proven that an increase in the Th1/Th2 ratio or T4/T8 index leads to an increased risk of miscarriage [51, $66,70-73]$. Several studies have pointed to an increase in natural killer cells in peripheral blood (pNK cells) in patients with RM compared to healthy controls [74-77]. Recent studies have also pointed to a significant increase in uterine natural killer cells (uNK cells) in patients with idiopathic RM $[78,79]$.

\section{Consensus-based Recommendation 3-7.E21}

\section{Expert consensus}

\section{Level of consensus ++}

Alloimmune investigations such as determining the Th1/Th2 ratio or the T4/T8 index, analysis of pNK and/or uNK cells, NK toxicity tests, lymphocyte function tests, molecular genetic testing for non-classical HLA groups (Ib) or KIR receptor families and determination of HLA should not be done in women with RM outside clinical studies, unless there is evidence of a preexisting autoimmune disorder.

\subsubsection{Autoimmune factors}

Although the data are not consistent, the majority of studies report increased ANA titer levels in women with RM [80-86]. Celiac disease is characterized by gluten sensitivity; its association with RM is still controversially discussed. Testing for immunoglobulin 
A $(\lg A)$ antibodies against tissue transglutaminase can be done in women with a history of food sensitivity (food intolerances, irregular bowel motions) and RM, followed by biopsy of the small intestine if the findings are positive [87].

Testing for antiphospholipid syndrome using clinical and laboratory parameters is recommended in women with RM ( $\bullet$ Fig. 1). Non-specific antibodies against anionic phospholipids such as cardiolipins and $\beta 2$ glycoproteins, also known as antiphospholipid antibodies ( $\mathrm{aPLAb}$ ) have been detected in some women with RM. However, according to the definition given in > Fig. 1, antiphospholipid (aPL) syndrome is only present if both clinical and laboratory criteria are fulfilled. Between $2 \%$ and $15 \%$ of women with RM suffer from aPL syndrome [88]. During the diagnostic workup, it is important to determine whether aPL antibody titer is still moderate to high at the 12-week follow-up after first determining the titer, i.e., whether it is in the > 99th percentile compared to unremarkable controls [89].

A few studies have considered the possibility of so-called “non-criteria” aPL syndrome, particularly when manifestations (livedo reticularis, ulcerations, renal microangiopathies, neurological disorders and cardiac manifestations) are present and the diagnostic criteria for classic aPL syndrome are not fulfilled or only in part (e.g., low aPLAb titer or s/p 2 miscarriages) [89].

\section{Consensus-based Recommendation 3-7.E22}

\section{Expert consensus}

Level of consensus +++

Testing for antiphospholipid syndrome based on clinical and laboratory parameters ( $\triangleright$ Fig. $\mathbf{1}$ ) is recommended for women with RM.

\section{\begin{tabular}{|l|l|}
\hline \multicolumn{2}{|c|}{ Consensus-based Recommendation 3-7.E23 } \\
\hline Expert consensus & Level of consensus +++ \\
\hline Interdisciplinary care must be offered to women with RM and an auto- \\
immune disease already present prior to conception.
\end{tabular}}

\section{Consensus-based Recommendation 3-7.E24}

\section{Expert consensus}

Level of consensus ++

Testing for non-criteria antiphospholipid syndrome based on clinical and laboratory parameters should be done in women with RM, particularly if clinical manifestations are present (livedo reticularis, ulcerations, renal microangiopathies, neurological disorders and cardiac manifestations).

\subsubsection{Treatment for immunological factors}

\subsubsection{Glucocorticoids}

The results of existing clinical studies which administered glucocorticoids to women with RM are inconsistent [90-93]. Treatment with glucocorticoids - particularly at higher doses - can induce side effects such as gestational diabetes, arterial hypertension, preterm birth, low birthweight (SGA) and disorders of neurological development in the infant [94-96]. This type of treatment

\section{Clinical criteria \\ $\checkmark \geq 1$ venous or arterial thrombosis \\ - 1 or 2 unexplained miscarriages of morphologically normal fetuses after the 10 th $\mathrm{GW}, \geq 3$ miscarriages before the 10th GW \\ $\checkmark \geq 1$ late miscarriage or preterm birth before the 34th GW because of placental insufficiency or preeclampsia}

Laboratory criteria (detected on 2 separate occasions at an interval of 12 weeks)

- Anti-cardiolipin antibodies (IgM, IgG) moderate to high titer

- Anti- $\beta 2$ glycoprotein 1 antibodies (lgM, IgG) high titer

- Lupus anticoagulant

- Fig. 1 Diagnostic criteria for antiphospholipid syndrome [89]. Clinical and laboratory criteria can be present either in combination or singly. By definition, however, at least one clinical and one laboratory criterion must be present to make a diagnosis of antiphospholipid syndrome. [rerif]

should therefore be reserved for patients with pre-existing autoimmune diseases which require therapy with glucocorticoids even during pregnancy.

\begin{tabular}{l}
\hline \multicolumn{1}{|c|}{ Consensus-based Recommendation 3-7.E25 } \\
\hline \multicolumn{1}{|c|}{ Expert consensus } \\
\hline $\begin{array}{l}\text { Glucocorticoids must not be administered outside clinical studies as pro- } \\
\text { phylaxis to prevent miscarriage in women with RM but without pre-existing } \\
\text { autoimmune disease. }\end{array}$
\end{tabular}

\subsubsection{Intravenous immunoglobulins}

A few studies have pointed out that intravenous administration of immunoglobulins (IVIG) reduces the concentrations and activities of natural killer cells in peripheral blood and affects Th1-mediated immune response [97]. The studies were very heterogeneous and the majority were done in patients with idiopathic RM but without a specific immunological diagnostic workup prior to starting therapy. The data is inconsistent [97-100].

A recent meta-analysis which included 11 randomized studies of the type described above found no significantly higher LBR for the group of patients who received IVIG (RR 0.92; 95\% Cl: $0.75-$ 1.12) compared to placebo or standard care [101]. A subgroup analysis showed a trend towards a benefit from IVIG in the cohort of patients with secondary RM compared to placebo (RR for no live births $0.77 ; 95 \% \mathrm{Cl}: 0.58-1.02 ; \mathrm{p}=0.06)$. There are currently no clearly defined indications for the administration of immunoglobulins, and they should therefore not be administered outside 
clinical studies. Side effects which can even include anaphylactic shock and the transmission of infectious pathogens are rare, but the incidence of occurrence is significantly higher in the verum group compared to controls.

Consensus-based Recommendation 3-7.E26

Expert consensus Level of consensus ++

Therapy with intravenous immunoglobulins to prevent miscarriage should not be given to women with RM outside clinical studies.

\subsubsection{Lipid infusion}

Current studies showed that soybean-oil-based lipid infusions reduced both NK cell activity and the formation of pro-inflammatory cytokines [102-106]. Small observational studies have shown that lipid infusions administered to women with RM or implantation failure and increased NK cell activity achieved the same live birth rates as treatment with IVIG [107-109]. A randomized placebo-controlled double-blind study carried out in Egypt investigated the impact of a single lipid infusion in a cohort von 296 women (with no tubal pathology and aged less than 40 years) undergoing IVF. The investigated women all had $\geq 3$ idiopathic RM (consecutive clinical miscarriages after spontaneous conception or IVF/ICSI) and had elevated levels of peripheral blood NK cells (pNK cells > 12\%) [110]. No significant difference in the rate of biochemical pregnancies was found between groups, but the rate of intact pregnancies $>12$ th GW and the rate of live births ( 37.5 vs. $22.4 \%$, respectively; $p=0.005$ ) was significantly higher in the group which had received a lipid infusion.

Consensus-based Recommendation 3-7.E27

\begin{tabular}{l|l} 
Expert consensus $\quad$ Level of consensus +++
\end{tabular}

Lipid infusion to prevent miscarriage should not be administered to women with RM outside clinical studies.

\subsubsection{Allogeneic lymphocyte transfer (LIT)}

The transfer of allogeneic lymphocytes (usually paternal lymphocytes, rarely donor lymphocytes, also known as lymphocyte immunization therapy) is a means of readying the maternal immune system to cope with the embryo's foreign antigens (HLA). The data on the uses of this therapy in women with RM is inconsistent. Two recent meta-analyses pointed to higher LBR in patients with idiopathic RM who received LIT. However, these meta-analyses were strongly influenced by the weighting of an Asian study, published in 2013, which showed a positive effect [111-113]. Older studies found no benefit [114-116], meaning that, here too, further studies will be necessary. It should be noted that the transfusion of blood products can lead to complications (e.g., transmission of infections, formation of irregular autoantibodies, induction of autoimmune disorders).
Consensus-based Recommendation 3-7.E28

Expert consensus Level of consensus +

Allogeneic lymphocyte transfer to prevent miscarriage should not be carried out in women with RM outside clinical studies.

\subsubsection{TNF- $\alpha$ receptor blockers}

Subgroups of patients with RM have been reported to have increased TNF- $\alpha$ concentrations, abnormal TNF- $\alpha / \mathrm{IL}-10$ ratios or numbers of TNF- $\alpha$-producing CD3+CD4+ lymphocytes, and these subgroups could benefit from the administration of TNF- $\alpha$ receptor blockers (e.g., adalimumab or infliximab) $[100,117]$. However, only one retrospective study has looked at this issue to date. In addition to TNF- $\alpha$ receptor blockers, the study also used low-dose acetylsalicylic acid (ASA), low-molecular-weight heparin (LMWH) and immunoglobulins [100]. Well-known side effects ranged from skin reactions to infections and even rare adverse events such as drug-induced lupus [118]. There are also concerns regarding the possible induction of malignant disease by TNF- $\alpha$ blockers [119]. At present, the administration of TNF- $\alpha$ receptor blockers should be reserved for controlled clinical studies and for specific conditions (e.g., autoimmune diseases such as Crohn's disease or chronic polyarthritis).

Consensus-based Recommendation 3-7.E29

\begin{tabular}{l|l} 
Expert consensus $\quad$ Level of consensus ++
\end{tabular}

Therapy with TNF- $\alpha$ receptor blockers should not be given to women with RM outside clinical studies.

\subsubsection{Treatment for autoimmune factors}

Because of the inconsistent data on the prevalence of antinuclear antibodies in women with RM, the current therapy strategies (ASA, glucocorticoids, low-molecular-weight heparin) are inconsistent and the guideline cannot offer any recommendations. There is currently only one retrospective study on the therapy of women with celiac disease and RM $(n=13)$ [120]. The women in the study benefitted from a gluten-free diet.

Therapy with low-dose acetylsalicylic acid and low-molecularweight heparin is recommended for women with RM and antiphospholipid syndrome. Treatment with acetylsalicylic acid and heparin must be initiated as soon as the pregnancy test is positive. Aspirin administration must continue until GW $34+0$, with heparin administration continuing for at least 6 weeks post partum. Numerous studies have shown that patients with RM and APS benefited from the administration of aspirin (50-100 mg/d) and low-molecular-weight heparin in prophylactic doses [121-125]. In contrast to the administration of LMWH and aspirin, other therapeutic approaches such as the administration of corticoids, immunoglobulins or aspirin alone did not result in any significant improvement in the LBR of patients with RM and APS [121].

Based on current studies, non-criteria aPL syndrome should be treated in exactly the same way, as a few studies have indicated a 
potential benefit from the administration of LMWH in combination with ASA [126-130].

\section{Consensus-based Recommendation 3-7.E30}

\section{Expert consensus}

Level of consensus +++

Therapy with low-dose acetylsalicylic acid and low-molecular-weight heparin is recommended for women with RM and antiphospholipid syndrome. Treatment with acetylsalicylic acid and heparin must be initiated as soon as the pregnancy test is positive. Aspirin administration must continue until GW $34+0$, with heparin administration continuing for at least 6 weeks post partum.

\section{Consensus-based Recommendation 3-7.E31}

\section{Expert consensus} Level of consensus +++

Therapy with low-dose acetylsalicylic acid and low-molecular-weight heparin is recommended for women with RM and non-criteria antiphospholipid syndrome. Treatment with acetylsalicylic acid and heparin must be initiated as soon as the pregnancy test is positive. Aspirin administration must continue until GW $34+0$, with heparin administration continuing for at least 6 weeks post partum.

\subsection{Coagulation}

\subsubsection{Diagnosis of congenital thrombophilic factors}

Hereditary thrombophilic parameters are present in up to $15 \%$ of the Caucasian population [131]. In recent years, the assessment of maternal thrombophilia as an important risk factor for RM has significantly changed. Thrombophilia testing done only to prevent miscarriage is not recommended. International guidelines (ASRM, ACCP, RCOG) do not recommend routine testing for hereditary thrombophilia in women with RM [1,3,132-134]. The RCOG guideline considers testing for maternal hereditary thrombophilia to be only indicated in the context of scientific studies [133]. The ASRM recommendations propose thrombophilia testing for women with RM only if they have a medical or familial history of thromboembolic events [1, 3,132-134].

Abnormalities in thrombophilic parameters may be an indication to treat pregnant women for medical reasons (prevention of thrombembolic events). Anticoagulation therapy to prevent maternal thromboembolism may be justified in pregnant women who have an increased risk of thromboembolic events (VTE) due to specific conditions (e.g., antithrombin deficiency, homozygous FVL mutation, combined heterozygous FVL and PT mutation, etc.) and in women with additional risk factors for VTE in pregnancy (immobilization, surgery, excessive weight gain, etc.) (ACOG 2013, AWMF 2015).

\section{Consensus-based Recommendation 3-8.E32}

\section{Expert consensus}

Level of consensus ++

Testing for thrombophilia to prevent miscarriage is not recommended.

\section{Consensus-based Recommendation 3-8.E33}

\section{Expert consensus} Level of consensus +++

Women with RM who are at risk of thromboembolic events must be tested for thrombophilia. This includes determination of antithrombin activity and plasma protein $C$ and protein $S$ levels and molecular genetic analysis for factor V Leiden mutation and prothrombin G20210A mutation.

\subsubsection{Treatment for women at risk of thrombophilic events}

\subsubsection{Heparin}

Unfractionated and low-molecular-weight heparins differ with regard to their molecular weight, plasma protein binding, biological half-life and rate of side effects. In addition to their anticoagulation effect, they also have numerous effects at the molecular level of the embryo-maternal interface which are still not completely understood [135]. No heparins cross the placenta. The administration of low-molecular-weight heparin(s) during pregnancy is considered comparatively safe [136]. The administration of heparins in pregnancy represents an off-label use. If the administration of heparin in pregnancy is indicated, low-molecular-weight heparins should be used because of their superior side-effects profile and ease of administration [132]. The enthusiasm at the turn of the century about the impact of prophylactic heparin administration in women with RM (in whom APS had been excluded) on the prevention of miscarriage could not be confirmed in either large prospective randomized studies [137-139] or in more recent meta-analyses [140].

The general maternal administration of heparin in subsequent pregnancies to women with RM without confirmed thrombophilia is not indicated because of the lack of proof of efficacy [141143]. There is also no evidence for a beneficial effect of administering heparin prior to or during the conception period on the prevention of further miscarriages.

To what extent subgroups of patients (e.g., patients with confirmed hereditary thrombophilia) actually benefit from the administration of heparin in subsequent pregnancies requires further studies, such as the currently recruiting, multinational ALIFE2 trial [144]. At present, the general administration of heparin outside clinical studies for the indication "prevention of miscarriage" alone is not indicated, even in thrombophilic women with RM (in whom APS has not been confirmed) $[132,145]$.

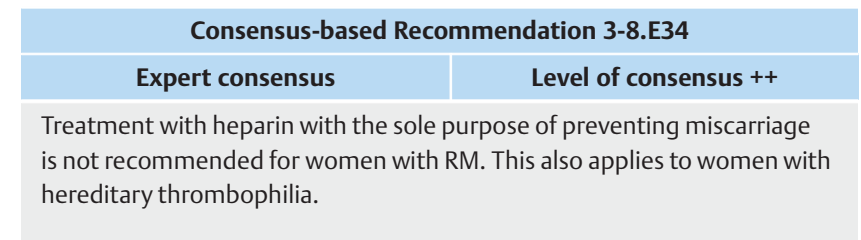


Consensus-based Recommendation 3-8.E35

Expert consensus

Level of consensus ++

Thromboprophylaxis for maternal indication should be given during pregnancy to women with RM and an increased risk of thromboembolic events.

\subsubsection{Acetylsalicylic acid (ASA)}

The use of ASA in pregnancy to prevent miscarriage represents an off-label use. The administration of ASA in low doses starting in the 1st trimester of pregnancy reduces the risk of placenta-associated complications in late pregnancy [146], although it has not been possible to confirm any protective effect on the rate of miscarriages. The prospective randomized ALIFE trial in women with idiopathic RM reported that administration of aspirin prior to conception ( $80 \mathrm{mg} /$ day) did not reduce the rate of miscarriages compared to placebo [138]. A systematic Cochrane meta-analysis found no benefit from the prophylactic administration of ASA in women with idiopathic RM (RR 0.94; 95\% Cl: 0.80-1.11) [147]. This also applies to the administration of aspirin prior to conception [148].

\section{Consensus-based Recommendation 3-8.E36}

Expert consensus

Level of consensus +++

Acetylsalicylic acid therapy to prevent miscarriage is not recommended for women with RM.

\subsubsection{Monitoring during pregnancy - D dimers}

Consensus-based Recommendation 3-8.E37

Expert consensus Level of consensus +++

Monitoring of plasma coagulation markers (D dimers, prothrombin fragments, etc.) during pregnancy is not recommended in women with RM. Determination of these markers must not be used as an indication to initiate therapy to prevent miscarriage.

\subsection{Idiopathic RM}

\subsubsection{Diagnosis of idiopathic RM}

Idiopathic RM is present if the criteria for a diagnosis of RM are met, and genetic, anatomical, endocrine, established immunological and hemostatic factors have been ruled out. The percentage of idiopathic RM in the total population of women with RM is high and amounts to 50-75\% [2]. The percentage of live births for women with idiopathic RM who did not receive treatment is 35$85 \%[138,149]$.

\section{Consensus-based Recommendation 3-9.E38}

Expert consensus

Level of consensus +++

The term "idiopathic RM" is only used if the diagnostic workup described in this guideline is carried out and no cause of RM has been found.

\subsubsection{Therapy for idiopathic RM}

A Cochrane meta-analysis of nine randomized studies which included 1228 women with idiopathic RM who had had at least two spontaneous miscarriages found no statistically significant effect of ASA with/without heparin on the LBR compared to placebo [147]. A randomized study of 364 women with idiopathic RM found that ASA administration had no impact on LBR compared to ASA and nadroparin or placebo [138]. Another meta-analysis of six randomized studies of 907 women with idiopathic RM also found no improvement in live birth rates following the administration of ASA and heparin [147].

\begin{tabular}{|l|l|}
\hline \multicolumn{2}{|c|}{ Consensus-based Recommendation 3-9.E39 } \\
\hline Expert consensus & Level of consensus ++ \\
\hline Treatment with acetylsalicylic acid with or without additional heparin to \\
prevent miscarriage is not recommended in women with idiopathic RM.
\end{tabular}

A meta-analysis, published in 2017, of 10 randomized studies of 1586 women with idiopathic RM reported a positive effect following therapy with progestogens in the first trimester of pregnancy, both in terms of the rate of miscarriages (RR 0.72; $95 \% \mathrm{Cl}$ : 0.53-0.97) and the rate of live births (RR $1.07 ; 95 \% \mathrm{Cl}: 1.02-$ 1.15). Synthetic progestogens, but not natural progesterone, were associated with a lower risk of recurrent miscarriage [150]. Synthetic progestogens can therefore be administered to women with idiopathic RM in the first trimester of pregnancy to prevent miscarriage. However, the optimal time for administration and the optimal dosage of the progestin are not yet clear.

In the PROMISE trial, a total of 836 women with idiopathic RM were randomized to receive either placebo or $400 \mathrm{mg}$ micronized progesterone applied by vaginal suppository [151]. Treatment was initiated soon after positive urinary pregnancy test and continued up to and including the 12th week of gestation. The LBR was the same in both study arms (63 and 66\%, respectively). However, a randomized study of 700 women with RM carried out in Egypt reported significantly higher live birth rates compared to placebo (91 vs. $77 \%$ ) for $2 \times 400 \mathrm{mg}$ progesterone administered intravaginally, starting in the luteal phase [152].

\begin{tabular}{l}
\hline \multicolumn{1}{|c|}{ Consensus-based Recommendation 3-9.E40 } \\
\hline \multicolumn{1}{|c|}{ Expert consensus } \\
\hline $\begin{array}{l}\text { Treatment with natural micronized progesterone in the first trimester of } \\
\text { pregnancy to prevent miscarriage is not recommended for women with } \\
\text { idiopathic RM. }\end{array}$
\end{tabular}

Consensus-based Recommendation 3-9.E40 Expert consensus Level of consensus ++

Synthetic progestogens can be administered to women with idiopathic RM in the first trimester of pregnancy to prevent miscarriage. 
The effect of human chorionic gonadotropin (hCG) in doses of 5000-10000 IE in the first and second trimester of pregnancy was evaluated in five randomized studies of 596 women with RM, including women with idiopathic RM. A Cochrane meta-analysis of these five studies found that the administration of hCG led to a significant reduction in the frequency of miscarriage. However, this positive effect was no longer statistically significant when the analysis was done without the two methodologically weaker studies (OR 0.74; 95\% Cl: 0.44-1.23) [153]. The studies did not include data on LBR. There was no separate subgroup analysis for women with idiopathic RM. It is therefore currently not possible to recommend the administration of hCG to treat women with RM.

Scarpellini et al. carried out a randomized study in 68 women with RM who had previously had at least 4 consecutive spontaneous miscarriages. The women were randomized to receive either placebo or rh-G-CSF $(1 \mu \mathrm{g} / \mathrm{kg} /$ day) starting on the 6th day after ovulation [154]. LBR for the active study arm was $83 \%$ (29/35) compared to $48 \%$ in the control group (16/33). In a retrospective cohort study Santjohanser et al. reported on 127 women with RM (for the purposes of that study, RM was defined as at least 2 spontaneous early miscarriages) who had IVF/ICSI [155]. Forty-nine of the women received either rh-G-CSF at a dose of 34 million units/ week or $2 \times 13$ million units/week until the 12 th week of gestation. The LBR was 32\% higher following G-CSF administration compared to $13-14 \%$ for other patient groups. As a number of issues (e.g., the optimal dose) relating to G-CSF therapy are still unresolved, G-CSF should only be administered in the context of a clinical study.

\begin{tabular}{|l|}
\hline \multicolumn{1}{|c|}{ Consensus-based Recommendation 3-9.E41 } \\
\hline Expert consensus \\
\hline $\begin{array}{l}\text { With the exception of clinical trials, administration of G-CSF to prevent } \\
\text { miscarriage is not recommended for women with idiopathic RM. }\end{array}$ \\
\hline
\end{tabular}

\section{Consensus-based Recommendation 3-9.E42}

Expert consensus

Level of consensus +++

Treatment with acetylsalicylic acid with or without additional heparin to prevent miscarriage is not recommended in women with idiopathic RM.

\section{Conflict of Interest}

Conflicts of interest are given in long version of the guideline.

\section{References}

[1] RCOG. The investigation and treatment of couples with recurrent firsttrimester and second-trimester miscarriage. In: RCOG Green-top Guideline No 17. Royal College of Obstetricians \& Gynaecologists; 2011. Online: https://www.rcog.org.uk/globalassets/documents/guidelines/ gtg_17.pdf; last access: 24.04.2018

[2] American College of Obstetricians and Gynecologists. ACOG practice bulletin. Management of recurrent pregnancy loss. Number 24, February 2001. (Replaces Technical Bulletin Number 212, September 1995). American College of Obstetricians and Gynecologists. Int J Gynaecol Obstet 2002; 78: 179-190

[3] ASRM Practice Committee. Evaluation and treatment of recurrent pregnancy loss: a committee opinion. Fertil Steril 2012; 98: 1103-1111

[4] Carrington B, Sacks G, Regan L. Recurrent miscarriage: pathophysiology and outcome. Curr Opin Obstet Gynecol 2005; 17: 591-597

[5] WHO. Recommended definitions, terminology and format for statistical tables related to the perinatal period and use of a new certificate for cause of perinatal deaths. Modifications recommended by FIGO as amended October 14 1976. Acta Obstet Gynecol Scand 1977; 56: 247253

[6] Practice Committee of tAmerican Society for Reproductive Medicine. Definitions of infertility and recurrent pregnancy loss. Fertil Steril 2008; 90 (5 Suppl.): S60

[7] Rai R, Regan L. Recurrent miscarriage. Lancet 2006; 368: 601-611

[8] Li TC, Makris M, Tomsu M et al. Recurrent miscarriage: aetiology, management and prognosis. Hum Reprod Update 2002; 8: 463-481

[9] Nybo Andersen AM, Wohlfahrt J, Christens P et al. Maternal age and fetal loss: population based register linkage study. BMJ 2000; 320: 17081712

[10] Li W, Newell-Price J, Jones GL et al. Relationship between psychological stress and recurrent miscarriage. Reprod Biomed Online 2012; 25: 180189

[11] Kolte AM, Olsen LR, Mikkelsen EM et al. Depression and emotional stress is highly prevalent among women with recurrent pregnancy loss. Hum Reprod 2015; 30: 777-782

[12] Greenwood DC, Alwan N, Boylan S et al. Caffeine intake during pregnancy, late miscarriage and stillbirth. Eur J Epidemiol 2010; 25: 275-280

[13] Maconochie N, Doyle P, Prior S et al. Risk factors for first trimester miscarriage-results from a UK-population-based case-control study. BJOG 2007; 114: 170-186

[14] Stefanidou EM, Caramellino L, Patriarca A et al. Maternal caffeine consumption and sine causa recurrent miscarriage. Eur J Obstet Gynecol Reprod Biol 2011; 158: 220-224

[15] Leung LW, Davies GA. Smoking cessation strategies in pregnancy. J Obstet Gynaecol Can 2015; 37: 791-797

[16] Zhang BY, Wei YS, Niu JM et al. Risk factors for unexplained recurrent spontaneous abortion in a population from southern China. Int J Gynaecol Obstet 2010; 108: 135-138

[17] Wilcox AJ, Weinberg CR, Baird DD. Risk factors for early pregnancy loss. Epidemiology 1990; 1: 382-385

[18] Venners SA, Wang X, Chen C et al. Paternal smoking and pregnancy loss: a prospective study using a biomarker of pregnancy. Am J Epidemiol 2004; 159: 993-1001

[19] Laurino MY, Bennett RL, Saraiya DS et al. Genetic evaluation and counseling of couples with recurrent miscarriage: recommendations of the National Society of Genetic Counselors. J Genet Couns 2005; 14: 165181 
[20] Robberecht C, Pexsters A, Deprest ] et al. Cytogenetic and morphological analysis of early products of conception following hystero-embryoscopy from couples with recurrent pregnancy loss. Prenat Diagn 2012; 32: 933-942

[21] Goddijn M, Leschot NJ. Genetic aspects of miscarriage. Baillieres Best Pract Res Clin Obstet Gynaecol 2000; 14: 855-865

[22] Philipp T, Philipp K, Reiner A et al. Embryoscopic and cytogenetic analysis of 233 missed abortions: factors involved in the pathogenesis of developmental defects of early failed pregnancies. Hum Reprod 2003; 18 : 1724-1732

[23] De Braekeleer M, Dao TN. Cytogenetic studies in couples experiencing repeated pregnancy losses. Hum Reprod 1990; 5: 519-528

[24] Franssen MT, Korevaar JC, Leschot NJ et al. Selective chromosome analysis in couples with two or more miscarriages: case-control study. BM] 2005; 331: 137-141

[25] Franssen MT, Korevaar JC, van der Veen F et al. Reproductive outcome after chromosome analysis in couples with two or more miscarriages: index [corrected]-control study. BM] 2006; 332: 759-763

[26] van den Berg MM, van Maarle MC, van Wely M et al. Genetics of early miscarriage. Biochim Biophys Acta 2012; 1822: 1951-1959

[27] Pereza N, Ostojić S, Kapović M et al. Systematic review and meta-analysis of genetic association studies in idiopathic recurrent spontaneous abortion. Fertil Steril 2017; 107: 150-159.e2

[28] Seckin B, Sarikaya E, Oruc AS et al. Office hysteroscopic findings in patients with two, three, and four or more, consecutive miscarriages. Eur J Contracept Reprod Health Care 2012; 17: 393-398

[29] Raga F, Casañ EM, Bonilla-Musoles F. Expression of vascular endothelial growth factor receptors in the endometrium of septate uterus. Fertil Steril 2009; 92: 1085-1090

[30] Ludwin A, Ludwin I, Banas T et al. Diagnostic accuracy of sonohysterography, hysterosalpingography and diagnostic hysteroscopy in diagnosis of arcuate, septate and bicornuate uterus. J Obstet Gynaecol Res 2011; 37: $178-186$

[31] Smit JG, Kasius JC, Eijkemans MJ et al. The international agreement study on the diagnosis of the septate uterus at office hysteroscopy in infertile patients. Fertil Steril 2013; 99: 2108-2113.e2

[32] Salim R, Regan L, Woelfer B et al. A comparative study of the morphology of congenital uterine anomalies in women with and without a history of recurrent first trimester miscarriage. Hum Reprod 2003; 18 : $162-166$

[33] Grimbizis GF, Di Spiezio Sardo A, Saravelos SH et al. The Thessaloniki ESHRE/ESGE consensus on diagnosis of female genital anomalies. Hum Reprod 2016; 31: 2-7

[34] Sunkara SK, Khairy M, El-Toukhy T et al. The effect of intramural fibroids without uterine cavity involvement on the outcome of IVF treatment: a systematic review and meta-analysis. Hum Reprod 2010; 25: 418-429

[35] Saravelos SH, Yan J, Rehmani H et al. The prevalence and impact of fibroids and their treatment on the outcome of pregnancy in women with recurrent miscarriage. Hum Reprod 2011; 26: 3274-3279

[36] Metwally M, Cheong YC, Horne AW. Surgical treatment of fibroids for subfertility. Cochrane Database Syst Rev 2012; (11): CD003857

[37] Valle RF, Ekpo GE. Hysteroscopic metroplasty for the septate uterus: review and meta-analysis. J Minim Invasive Gynecol 2013; 20: 22-42

[38] Rikken JF, Kowalik CR, Emanuel MH et al. Septum resection for women of reproductive age with a septate uterus. Cochrane Database Syst Rev 2017; (1): CD008576

[39] Yang JH, Chen M], Chen CD et al. Optimal waiting period for subsequent fertility treatment after various hysteroscopic surgeries. Fertil Steril 2013; 99: 2092-2096.e3

[40] Sugiura-Ogasawara M, Ozaki Y, Katano K et al. Uterine anomaly and recurrent pregnancy loss. Semin Reprod Med 2011; 29: 514-521
[41] Jaslow CR. Uterine factors. Obstet Gynecol Clin North Am 2014; 41: 57 86

[42] Bailey AP, Jaslow CR, Kutteh WH. Minimally invasive surgical options for congenital and acquired uterine factors associated with recurrent pregnancy loss. Womens Health (Lond) 2015; 11: 161-167

[43] Conforti A, Alviggi C, Mollo A et al. The management of Asherman syndrome: a review of literature. Reprod Biol Endocrinol 2013; 11: 118

[44] Bosteels J, Weyers S. Outpatient treatment for uterine polyps. BM] 2015 350: h1469

[45] Johnston-MacAnanny EB, Hartnett ], Engmann LL et al. Chronic endometritis is a frequent finding in women with recurrent implantation failure after in vitro fertilization. Fertil Steril 2010; 93: 437-441

[46] Zolghadri J, Momtahan M, Aminiam K et al. The value of hysteroscopy in diagnosis of chronic endometritis in patients with unexplained recurrent spontaneous abortion. Eur J Obstet Gynecol Reprod Biol 2011; 155: 217-220

[47] Cicinelli E, Matteo M, Tinelli R et al. Chronic endometritis due to common bacteria is prevalent in women with recurrent miscarriage as confirmed by improved pregnancy outcome after antibiotic treatment. Reprod Sci 2014; 21: 640-647

[48] McQueen DB, Bernardi LA, Stephenson MD. Chronic endometritis in women with recurrent early pregnancy loss and/or fetal demise. Fertil Steril 2014; 101: 1026-1030

[49] Yang R, Du X, Wang Y et al. The hysteroscopy and histological diagnosis and treatment value of chronic endometritis in recurrent implantation failure patients. Arch Gynecol Obstet 2014; 289: 1363-1369

[50] Nigro G, Mazzocco M, Mattia E et al. Role of the infections in recurrent spontaneous abortion. J Matern Fetal Neonatal Med 2011; 24: 983-989

[51] Ng SC, Gilman-Sachs A, Thaker P et al. Expression of intracellular Th1 and Th2 cytokines in women with recurrent spontaneous abortion, implantation failures after IVF/ET or normal pregnancy. Am J Reprod Immunol 2002; 48: 77-86

[52] Anselmo J, Cao D, Karrison T et al. Fetal loss associated with excess thyroid hormone exposure. JAMA 2004; 292: 691-695

[53] van Dijk MM, Vissenberg R, Bisschop PH et al. Is subclinical hypothyroidism associated with lower live birth rates in women who have experienced unexplained recurrent miscarriage? Reprod Biomed Online 2016; 33: 745-751

[54] Thangaratinam S, Tan A, Knox E et al. Association between thyroid autoantibodies and miscarriage and preterm birth: meta-analysis of evidence. BMJ 2011; 342: d2616

[55] Cocksedge KA, Saravelos SH, Wang Q et al. Does free androgen index predict subsequent pregnancy outcome in women with recurrent miscarriage? Hum Reprod 2008; 23: 797-802

[56] Craig LB, Ke RW, Kutteh WH. Increased prevalence of insulin resistance in women with a history of recurrent pregnancy loss. Fertil Steril 2002; 78: 487-490

[57] Tian L, Shen H, Lu Q et al. Insulin resistance increases the risk of spontaneous abortion after assisted reproduction technology treatment. J Clin Endocrinol Metab 2007; 92: 1430-1433

[58] Melamed N, Hod M. Perinatal mortality in pregestational diabetes. Int J Gynaecol Obstet 2009; 104 (Suppl. 1): S20-S24

[59] Christiansen OB. Evidence-based investigations and treatments of recurrent pregnancy loss. Curr Opin Obstet Gynecol 2006; 18: 304-312

[60] Negro R, Schwartz A, Stagnaro-Green A. Impact of levothyroxine in miscarriage and preterm delivery rates in first trimester thyroid antibodypositive women with TSH less than $2.5 \mathrm{mIU} / \mathrm{L}$. J Clin Endocrinol Metab 2016; 101: 3685-3690

[61] Palomba S, Falbo A, Orio F jr. et al. Effect of preconceptional metformin on abortion risk in polycystic ovary syndrome: a systematic review and meta-analysis of randomized controlled trials. Fertil Steril 2009; 92: 1646-1658 
[62] Hahn KA, Hatch EE, Rothman KJ et al. Body size and risk of spontaneous abortion among danish pregnancy planners. Paediatr Perinat Epidemiol 2014; 28: 412-423

[63] Kentenich H, Wischmann T, Stöbel-Richter $\mathrm{Y}$, Hrsg. Fertilitätsstörungen - psychosomatisch orientierte Diagnostik und Therapie. Leitlinie und Quellentext (Revision). Gießen: Psychosozial-Verlag; 2013

[64] Catherino WH. Stress relief to augment fertility: the pressure mounts. Fertil Steril 2011; 95: 2462-2463

[65] Kwak-Kim J, Lee SK, Gilman-Sachs A. Elevated Th1/Th2 cell ratios in a pregnant woman with a history of RSA, secondary Sjogren's syndrome and rheumatoid arthritis complicated with one fetal demise of twin pregnancy. Am J Reprod Immunol 2007; 58: 325-329

[66] Kwak-Kim JY, Chung-Bang HS, Ng SC et al. Increased T helper 1 cytokine responses by circulating $T$ cells are present in women with recurrent pregnancy losses and in infertile women with multiple implantation failures after IVF. Hum Reprod 2003; 18: 767-773

[67] Romagnani P, Annunziato F, Piccinni MP et al. Th1/Th2 cells, their associated molecules and role in pathophysiology. Eur Cytokine Netw 2000; 11: $510-511$

[68] Piccinni MP, Scaletti G, Vultaggio A et al. Defective production of LIF, $\mathrm{M}$-CSF and Th2-type cytokines by T cells at fetomaternal interface is associated with pregnancy loss. J Reprod Immunol 2001; 52: 35-43

[69] Yuan J, Li J, Huang SY et al. Characterization of the subsets of human NKT-like cells and the expression of Th1/Th2 cytokines in patients with unexplained recurrent spontaneous abortion. J Reprod Immunol 2015; 110: $81-88$

[70] Raghupathy R, Makhseed M, Azizieh F et al. Cytokine production by maternal lymphocytes during normal human pregnancy and in unexplained recurrent spontaneous abortion. Hum Reprod 2000; 15: 713-718

[71] Lee SK, Na BJ, Kim JY et al. Determination of clinical cellular immune markers in women with recurrent pregnancy loss. Am J Reprod Immunol 2013; 70: 398-411

[72] Makhseed M, Raghupathy R, Azizieh F et al. Th1 and Th2 cytokine profiles in recurrent aborters with successful pregnancy and with subsequent abortions. Hum Reprod 2001; 16: 2219-2226

[73] Shimada S, Iwabuchi K, Kato EH et al. No difference in natural-killer-T cell population, but Th2/Tc2 predominance in peripheral blood of recurrent aborters. Am J Reprod Immunol 2003; 50: 334-339

[74] Kuon RJ, Müller F, Vomstein K et al. Pre-pregnancy levels of peripheral natural killer cells as markers for immunomodulatory treatment in patients with recurrent miscarriage. Arch Immunol Ther Exp (Warsz) 2017; 65: 339-346

[75] Kwak JY, Beaman KD, Gilman-Sachs A et al. Up-regulated expression of CD56+, CD56+/CD16+, and CD19+ cells in peripheral blood lymphocytes in pregnant women with recurrent pregnancy losses. Am J Reprod Immunol 1995; 34: 93-99

[76] King K, Smith S, Chapman M et al. Detailed analysis of peripheral blood natural killer (NK) cells in women with recurrent miscarriage. Hum Reprod 2010; 25: 52-58

[77] Karami N, Boroujerdnia MG, Nikbakht R et al. Enhancement of peripheral blood CD56(dim) cell and NK cell cytotoxicity in women with recurrent spontaneous abortion or in vitro fertilization failure. J Reprod Immunol 2012; 95: 87-92

[78] Kuon RJ, Weber M, Heger J et al. Uterine natural killer cells in patients with idiopathic recurrent miscarriage. Am J Reprod Immunol 2017. doi:10.1111/aji.12721

[79] Gao Y, Wang PL. Increased CD56(+) NK cells and enhanced Th1 responses in human unexplained recurrent spontaneous abortion. Genet Mol Res 2015; 14: 18103-18109

[80] Kaider AS, Kaider BD, Janowicz PB et al. Immunodiagnostic evaluation in women with reproductive failure. Am J Reprod Immunol 1999; 42: 335346
[81] Matsubayashi H, Sugi T, Arai T et al. Different antiphospholipid antibody specificities are found in association with early repeated pregnancy loss versus recurrent IVF-failure patients. Am J Reprod Immunol 2001; 46: 323-329

[82] Giasuddin AS, Mazhar I, Haq AM. Prevalence of anticardiolipin antibody in Bangladeshi patients with recurrent pregnancy loss. Bangladesh Med Res Counc Bull 2010; 36: 10-13

[83] Ticconi C, Rotondi F, Veglia $\mathrm{M}$ et al. Antinuclear autoantibodies in women with recurrent pregnancy loss. Am J Reprod Immunol 2010; 64: 384392

[84] Molazadeh M, Karimzadeh H, Azizi MR. Prevalence and clinical significance of antinuclear antibodies in Iranian women with unexplained recurrent miscarriage. Iran J Reprod Med 2014; 12: 221-226

[85] Hefler-Frischmuth K, Walch K, Hefler L et al. Serologic markers of autoimmunity in women with recurrent pregnancy loss. Am J Reprod Immunol 2017. doi:10.1111/aji.12635

[86] Bustos D, Moret A, Tambutti M et al. Autoantibodies in Argentine women with recurrent pregnancy loss. Am J Reprod Immunol 2006; 55: 201 207

[87] Kumar A, Meena M, Begum N et al. Latent celiac disease in reproductive performance of women. Fertil Steril 2011; 95: 922-927

[88] Branch DW, Gibson M, Silver RM. Clinical practice. Recurrent miscarriage. N Engl J Med 2010; 363: 1740-1747

[89] Miyakis S, Lockshin MD, Atsumi T et al. International consensus statement on an update of the classification criteria for definite antiphospholipid syndrome (APS). J Thromb Haemost 2006; 4: 295-306

[90] Gomaa MF, Elkholy AG, El-Said MM et al. Combined oral prednisolone and heparin versus heparin: the effect on peripheral NK cells and clinical outcome in patients with unexplained recurrent miscarriage. A doubleblind placebo randomized controlled trial. Arch Gynecol Obstet 2014; 290: 757-762

[91] Fawzy M, Shokeir T, El-Tatongy $M$ et al. Treatment options and pregnancy outcome in women with idiopathic recurrent miscarriage: a randomized placebo-controlled study. Arch Gynecol Obstet 2008; 278: 33-38

[92] Tempfer CB, Kurz C, Bentz EK et al. A combination treatment of prednisone, aspirin, folate, and progesterone in women with idiopathic recurrent miscarriage: a matched-pair study. Fertil Steril 2006; 86: 145-148

[93] Tang AW, Alfirevic Z, Turner MA et al. A feasibility trial of screening women with idiopathic recurrent miscarriage for high uterine natural killer cell density and randomizing to prednisolone or placebo when pregnant. Hum Reprod 2013; 28: 1743-1752

[94] Hasbargen U, Reber D, Versmold H et al. Growth and development of children to 4 years of age after repeated antenatal steroid administration. Eur J Pediatr 2001; 160: 552-555

[95] Laskin CA, Bombardier C, Hannah ME et al. Prednisone and aspirin in women with autoantibodies and unexplained recurrent fetal loss. N Engl J Med 1997; 337: 148-153

[96] Gur C, Diav-Citrin O, Shechtman S et al. Pregnancy outcome after first trimester exposure to corticosteroids: a prospective controlled study. Reprod Toxicol 2004; 18: 93-101

[97] Stephenson MD, Kutteh WH, Purkiss S et al. Intravenous immunoglobulin and idiopathic secondary recurrent miscarriage: a multicentered randomized placebo-controlled trial. Hum Reprod 2010; 25: 2203-2209

[98] Ata B, Tan SL, Shehata F et al. A systematic review of intravenous immunoglobulin for treatment of unexplained recurrent miscarriage. Fertil Steril 2011; 95: 1080-5.e1-1080-5.e2

[99] Ensom MH, Stephenson MD. A two-center study on the pharmacokinetics of intravenous immunoglobulin before and during pregnancy in healthy women with poor obstetrical histories. Hum Reprod 2011; 26: 2283-2288 
[100] Winger EE, Reed JL. Treatment with tumor necrosis factor inhibitors and intravenous immunoglobulin improves live birth rates in women with recurrent spontaneous abortion. Am J Reprod Immunol 2008; 60: 8-16

[101] Egerup P, Lindschou J, Gluud C et al. The effects of intravenous immunoglobulins in women with recurrent miscarriages: a systematic review of randomised trials with meta-analyses and trial sequential analyses including individual patient data. PLoS One 2015; 10: e0141588

[102] Granato D, Blum S, Rössle C et al. Effects of parenteral lipid emulsions with different fatty acid composition on immune cell functions in vitro. JPEN J Parenter Enteral Nutr 2000; 24: 113-118

[103] Roussev RG, Ng SC, Coulam CB. Natural killer cell functional activity suppression by intravenous immunoglobulin, intralipid and soluble human leukocyte antigen-G. Am J Reprod Immunol 2007; 57: 262-269

[104] Roussev RG, Acacio B, Ng SC et al. Duration of intralipid's suppressive effect on NK cell's functional activity. Am J Reprod Immunol 2008; 60: 258-263

[105] Roussev RG, Dons'koi BV, Stamatkin C et al. Preimplantation factor inhibits circulating natural killer cell cytotoxicity and reduces CD69 expression: implications for recurrent pregnancy loss therapy. Reprod Biomed Online 2013; 26: 79-87

[106] Mayer K, Meyer S, Reinholz-Muhly M et al. Short-time infusion of fish oil-based lipid emulsions, approved for parenteral nutrition, reduces monocyte proinflammatory cytokine generation and adhesive interaction with endothelium in humans. J Immunol 2003; 171: 4837-4843

[107] Coulam CB, Acacio B. Does immunotherapy for treatment of reproductive failure enhance live births? Am J Reprod Immunol 2012; 67: 296-304

[108] Moraru M, Carbone J, Alecsandru D et al. Intravenous immunoglobulin treatment increased live birth rate in a Spanish cohort of women with recurrent reproductive failure and expanded CD56(+) cells. Am J Reprod Immunol 2012; 68: 75-84

[109] Meng L, Lin J, Chen L et al. Effectiveness and potential mechanisms of intralipid in treating unexplained recurrent spontaneous abortion. Arch Gynecol Obstet 2016; 294: 29-39

[110] Dakhly DM, Bayoumi YA, Sharkawy M et al. Intralipid supplementation in women with recurrent spontaneous abortion and elevated levels of natural killer cells. Int J Gynaecol Obstet 2016; 135: 324-327

[111] Porter TF, LaCoursiere Y, Scott JR. Immunotherapy for recurrent miscarriage. Cochrane Database Syst Rev 2006; (2): CD000112

[112] Cavalcante MB, Sarno M, Araujo Júnior E et al. Lymphocyte immunotherapy in the treatment of recurrent miscarriage: systematic review and meta-analysis. Arch Gynecol Obstet 2017; 295: 511-518

[113] Liu Z, Xu H, Kang X et al. Allogenic lymphocyte immunotherapy for unexplained recurrent spontaneous abortion: a meta-analysis. Am J Reprod Immunol 2016; 76: 443-453

[114] Christiansen OB, Mathiesen O, Husth M et al. Placebo-controlled trial of active immunization with third party leukocytes in recurrent miscarriage. Acta Obstet Gynecol Scand 1994; 73: 261-268

[115] Illeni MT, Marelli G, Parazzini F et al. Immunotherapy and recurrent abortion: a randomized clinical trial. Hum Reprod 1994; 9: 1247-1249

[116] Cauchi MN, Lim D, Young DE et al. Treatment of recurrent aborters by immunization with paternal cells-controlled trial. Am J Reprod Immunol 1991; 25: 16-17

[117] Lee BE, Jeon YJ, Shin JE et al. Tumor necrosis factor- $\alpha$ gene polymorphisms in Korean patients with recurrent spontaneous abortion. Reprod Sci 2013; 20: 408-413

[118] Rychly DJ, DiPiro JT. Infections associated with tumor necrosis factoralpha antagonists. Pharmacotherapy 2005; 25: 1181-1192

[119] Fellermann K. Adverse events of tumor necrosis factor inhibitors. Dig Dis 2013; 31: 374-378
[120] Tursi A, Giorgetti G, Brandimarte G et al. Effect of gluten-free diet on pregnancy outcome in celiac disease patients with recurrent miscarriages. Dig Dis Sci 2008; 53: 2925-2928

[121] Empson M, Lassere M, Craig J et al. Prevention of recurrent miscarriage for women with antiphospholipid antibody or lupus anticoagulant. Cochrane Database Syst Rev 2005; (2): CD002859

[122] Empson M, Lassere M, Craig JC et al. Recurrent pregnancy loss with antiphospholipid antibody: a systematic review of therapeutic trials. Obstet Gynecol 2002; 99: 135-144

[123] Mak A, Cheung MW, Cheak AA et al. Combination of heparin and aspirin is superior to aspirin alone in enhancing live births in patients with recurrent pregnancy loss and positive anti-phospholipid antibodies: a meta-analysis of randomized controlled trials and meta-regression. Rheumatology (Oxford) 2010; 49: 281-288

[124] Ziakas PD, Pavlou M, Voulgarelis M. Heparin treatment in antiphospholipid syndrome with recurrent pregnancy loss: a systematic review and meta-analysis. Obstet Gynecol 2010; 115: 1256-1262

[125] American College of Obstetricians and Gynecologists Committee on Practice Bulletins-Obstetrics. ACOG Practice Bulletin No. 118: antiphospholipid syndrome. Obstet Gynecol 2011; 117: 192-199

[126] Gardiner C, Hills ], Machin S] et al. Diagnosis of antiphospholipid syndrome in routine clinical practice. Lupus 2013; 22: 18-25

[127] Cohn DM, Goddijn M, Middeldorp $S$ et al. Recurrent miscarriage and antiphospholipid antibodies: prognosis of subsequent pregnancy. J Thromb Haemost 2010; 8: 2208-2213

[128] Alijotas-Reig J, Ferrer-Oliveras R; EUROAPS Study Group. The European Registry on Obstetric Antiphospholipid Syndrome (EUROAPS): a preliminary first year report. Lupus 2012; 21: 766-768

[129] Mekinian A, Loire-Berson P, Nicaise-Roland P et al. Outcomes and treatment of obstetrical antiphospholipid syndrome in women with low antiphospholipid antibody levels. J Reprod Immunol 2012; 94: 222-226

[130] Arachchillage DR, Machin SJ, Mackie IJ et al. Diagnosis and management of non-criteria obstetric antiphospholipid syndrome. Thromb Haemost 2015; 113: 13-19

[131] Roberts LN, Patel RK, Arya R. Venous thromboembolism and ethnicity. $\mathrm{Br}$ J Haematol 2009; 146: 369-383

[132] Bates SM, Greer IA, Middeldorp S et al. VTE, thrombophilia, antithrombotic therapy, and pregnancy: Antithrombotic Therapy and Prevention of Thrombosis, 9th ed: American College of Chest Physicians EvidenceBased Clinical Practice Guidelines. Chest 2012; 141 (2 Suppl.): e691Se736s

[133] Jauniaux E, Farquharson RG, Christiansen OB et al. Evidence-based guidelines for the investigation and medical treatment of recurrent miscarriage. Hum Reprod 2006; 21: 2216-2222

[134] Practice Committee of the American Society for Reproductive Medicine. Definitions of infertility and recurrent pregnancy loss. Fertil Steril 2008; 89: 1603

[135] Bohlmann MK. Effects and effectiveness of heparin in assisted reproduction. J Reprod Immunol 2011; 90: 82-90

[136] Bauersachs RM, Dudenhausen J, Faridi A et al. Risk stratification and heparin prophylaxis to prevent venous thromboembolism in pregnant women. Thromb Haemost 2007; 98: 1237-1245

[137] Clark P, Walker ID, Langhorne P et al.; Scottish Pregnancy Intervention Study (SPIN) collaborators. SPIN (Scottish Pregnancy Intervention) study: a multicenter, randomized controlled trial of low-molecularweight heparin and low-dose aspirin in women with recurrent miscarriage. Blood 2010; 115: 4162-4167

[138] Kaandorp SP, Goddijn M, van der Post JA et al. Aspirin plus heparin or aspirin alone in women with recurrent miscarriage. N Engl ] Med 2010; 362: 1586-1596 
[139] Schleussner E, Petroff D. Low-molecular-weight heparin for women with unexplained recurrent pregnancy loss. Ann Intern Med 2015; 163: 485

[140] Rodger MA, Gris JC, de Vries JIP et al. Low-molecular-weight heparin and recurrent placenta-mediated pregnancy complications: a metaanalysis of individual patient data from randomised controlled trials. Lancet 2016; 388: 2629-2641

[141] de Jong PG, Goddijn M, Middeldorp S. Antithrombotic therapy for pregnancy loss. Hum Reprod Update 2013; 19: 656-673

[142] Check JH. The use of heparin for preventing miscarriage. Am J Reprod Immunol 2012; 67: 326-333

[143] Gris JC. LMWH have no place in recurrent pregnancy loss: debateagainst the motion. Thromb Res 2011; 127 (Suppl. 3): S110-S112

[144] de Jong PG, Quenby S, Bloemenkamp KW et al. ALIFE2 study: low-molecular-weight heparin for women with recurrent miscarriage and inherited thrombophilia-study protocol for a randomized controlled trial. Trials 2015; 16: 208

[145] Tan WK, Lim SK, Tan LK et al. Does low-molecular-weight heparin improve live birth rates in pregnant women with thrombophilic disorders? A systematic review. Singapore Med J 2012; 53: 659-663

[146] Rolnik DL, Wright D, Poon LC et al. Aspirin versus placebo in pregnancies at high risk for preterm preeclampsia. N Engl ] Med 2017; 377: 613-622

[147] de Jong PG, Kaandorp S, Di Nisio M et al. Aspirin and/or heparin for women with unexplained recurrent miscarriage with or without inherited thrombophilia. Cochrane Database Syst Rev 2014; (7): CD004734
[148] Schisterman EF, Silver RM, Lesher LL et al. Preconception low-dose aspirin and pregnancy outcomes: results from the EAGeR randomised trial. Lancet 2014; 384: 29-36

[149] Liddell HS, Pattison NS, Zanderigo A. Recurrent miscarriage-outcome after supportive care in early pregnancy. Aust N Z J Obstet Gynaecol 1991; 31: 320-322

[150] Saccone G, Schoen C, Franasiak JM et al. Supplementation with progestogens in the first trimester of pregnancy to prevent miscarriage in women with unexplained recurrent miscarriage: a systematic review and meta-analysis of randomized, controlled trials. Fertil Steril 2017; 107: 430-438.e3

[151] Coomarasamy A, Williams H, Truchanowicz E et al. A randomized tria of progesterone in women with recurrent miscarriages. $N$ Engl J Med 2015; 373: 2141-2148

[152] Ismail AM, Abbas AM, Ali MK et al. Peri-conceptional progesterone treatment in women with unexplained recurrent miscarriage: a randomized double-blind placebo-controlled trial. J Matern Fetal Neonatal Med 2018; 31: 388-394

[153] Scott JR, Pattison N. Human chorionic gonadotrophin for recurrent miscarriage. Cochrane Database Syst Rev 2000; (2): CD000101

[154] Scarpellini F, Sbracia M. Use of granulocyte colony-stimulating factor for the treatment of unexplained recurrent miscarriage: a randomised controlled trial. Hum Reprod 2009; 24: 2703-2708

[155] Santjohanser C, Knieper C, Franz C et al. Granulocyte-colony stimulating factor as treatment option in patients with recurrent miscarriage. Arch Immunol Ther Exp (Warsz) 2013; 61: 159-164 


\section{Guideline Program}

\section{Editors}

Leading Professional Medical Associations

\section{Ty}

German Society of Gynecology and Obstetrics (Deutsche Gesellschaft für Gynäkologie und Geburtshilfe e. V. [DGGG])

Head Office of DGGG and Professional Societies Hausvogteiplatz 12, DE-10117 Berlin info@dggg.de

http://www.dggg.de/

\section{President of DGGG}

Prof. Dr. Birgit Seelbach-Göbel

Universität Regensburg

Klinik für Geburtshilfe und Frauenheilkunde

St. Hedwig-Krankenhaus Barmherzige Brüder

Steinmetzstraße 1-3, DE-93049 Regensburg

\section{DGGG Guidelines Representatives}

Prof. Dr. med. Matthias W. Beckmann Universitätsklinikum Erlangen, Frauenklinik Universitätsstraße 21-23, DE-91054 Erlangen

Prof. Dr. med. Erich-Franz Solomayer Universitätsklinikum des Saarlandes Geburtshilfe und Reproduktionsmedizin Kirrberger Straße, Gebäude 9, DE-66421 Homburg

\section{Guidelines Coordination}

Dr. med. Paul Gaß, Christina Fuchs, Marion Gebhardt Universitätsklinikum Erlangen, Frauenklinik Universitätsstraße 21-23, DE-91054 Erlangen fk-dggg-leitlinien@uk-erlangen.de http://www.dggg.de/leitlinienstellungnahmen

\section{OEGGG}

Austrian Society of Gynecology and Obstetrics (Österreichische Gesellschaft für Gynäkologie und Geburtshilfe [OEGGG]) Innrain 66A, AT-6020 Innsbruck stephanie.leutgeb@oeggg.at http://www.oeggg.at

\section{President of OEGGG}

Prof. Dr. med. Petra Kohlberger

Universitätsklinik für Frauenheilkunde Wien

Währinger Gürtel 18-20, AT-1180 Wien

\section{OEGGG Guidelines Representatives}

Prof. Dr. med. Karl Tamussino

Universitätsklinik für Frauenheilkunde und Geburtshilfe Graz Auenbruggerplatz 14, AT-8036 Graz

Prof. Dr. med. Hanns Helmer Universitätsklinik für Frauenheilkunde Wien Währinger Gürtel 18-20, AT-1090 Wien

\section{gynécologie}

Swiss Society of Gynecology and Obstetrics (Schweizerische Gesellschaft für Gynäkologie und Geburtshilfe [SGGG])

Gynécologie Suisse SGGG Altenbergstraße 29, Postfach 6, CH-3000 Bern 8 sekretariat@sggg.ch http://www.sggg.ch/

\section{President of SGGG}

Dr. med. David Ehm

FMH für Geburtshilfe und Gynäkologie

Nägeligasse 13, CH-3011 Bern

\section{SGGG Guidelines Representatives}

Prof. Dr. med. Daniel Surbek Universitätsklinik für Frauenheilkunde Geburtshilfe und feto-maternale Medizin Inselspital Bern Effingerstraße 102, CH-3010 Bern

Prof. Dr. med. René Hornung Kantonsspital St. Gallen, Frauenklinik Rorschacher Straße 95, CH-9007 St. Gallen 